\title{
A STUDY OF FACULTY GOVERNANCE LEADERS' PERCEPTIONS OF ONLINE AND BLENDED LEARNING
}

\author{
Elizabeth Ciabocchi \\ St. John's University \\ Amy Ginsberg \\ Long Island University \\ Anthony Picciano \\ City University of New York
}

\begin{abstract}
This article reports the findings of a study on the perceptions of faculty governance leaders to online and blended learning. For the purposes of this study, faculty governance was defined as formally established bodies in colleges and universities such as senates, councils, and collective bargaining organizations that are affiliated with the American Association of University Professors (AAUP). While there have been many studies on the perceptions of students, faculty, and administrators, there has been very little research on the perceptions of faculty governance leaders who hold critical positions in colleges and universities. Governance leaders are at the crux of approval processes that influence the development of curricula, faculty personnel policies, and academic programs, all of which can impact the implementation of online and blended learning initiatives. The research methodology for this study included a survey sent to a sample of governance leaders at U.S. institutions of higher education and follow-up phone interviews or email correspondence with a small number of volunteers. The sample was identified using an American Association of University Professors (AAUP) membership list. The results of this study provide important new information on the perceptions of this influential group of leaders on matters related to online and blended learning.
\end{abstract}




\section{Introduction}

Isador Isaac (I.I.) Rabi was a professor of physics at Columbia University who won the Nobel Prize in 1944 for his resonance method of recording the magnetic properties of atomic nuclei. He was widely regarded as one of the top physicists of his time and was a colleague of Niels Bohr, Wolfgang Pauli, and Werner Heisenberg. Rabi was instrumental in establishing Brookhaven National Laboratory and Nevis Labs (at Columbia University). He was also generally credited with giving European physicists the idea for establishing CERN (Conseil Européen pour la Recherche Nucléaire) Laboratory in Geneva. Rabi is also remembered for an encounter with Dwight D. Eisenhower, the president of Columbia University at the time. In 1948, at their first meeting, Eisenhower congratulated Rabi on his Nobel Prize for Physics, adding that he was always happy to see "one of Columbia's employees honored." The remark, it is recorded, drew from Rabi a careful response: "Mr. President, the faculty are not employees of the University - they are the University." This was the beginning of twenty years of friendship between the two (Devons, 2001).

Professors would like to think that Rabi's position on the importance of the faculty holds today, and in many universities, there is some truth to this. Faculty governing bodies, collective bargaining unions, and institutional bylaws that give professors extensive responsibilities and powers to hire new colleagues, to grant tenure, to establish curricula, and to evaluate teaching and learning are wellestablished in many of the universities in the country. It is through shared governance that the faculty can exert a "we are the university" mentality. While in some cases, this "we" has evolved to place faculty in an adversarial relationship with the administration, such does not have to be the case. Collaborative consensus between faculty governing bodies and administrations is common on many campuses and can be most beneficial. A prime example occurred at the University of Virginia in 2012, when President Teresa Sullivan was abruptly asked to resign by the Board of Visitors (trustees). As reported in the New York Times:

Some members of the Board of Visitors, most of whom are business executives, appear to have been shaken by the way prestigious institutions like M.I.T., Stanford and Harvard have dived into the online [learning] realm, and wondered if the University of Virginia was being left behind.

Ms. Sullivan said she perceived the many threats to the university, but favored addressing them in a collaborative, incremental way, not the more aggressive, top-down approach favored by the head of the board, or rector, Helen E. Dragas, and the former vice rector, Mark Kington, who were the driving forces behind the president's [Sullivan’s] ouster. (Perez-Pena, 2012)

Sixteen days after being asked to resign and after an outcry at the University led by the Faculty Senate's Executive Committee and thirty-three academic department chairpersons, President Sullivan was reinstated (de Vise and Kumar, 2012).

In recent years, one of the governance areas in which faculty have become particularly active is in the design and implementation of online education. Since first introduced in the 1990s, developments in online education have advanced significantly so that millions of college students are now enrolled in online courses and programs every year. A number of issues related to workload; compensation; contractual services; professional development; intellectual property; student evaluations, and control of curriculum and program decisions have evolved that have, at times, led to confrontations between faculty governance leaders and administrators. While there have been numerous articles and studies commenting on the views of faculty in general to online education, there have been hardly any of faculty governance leaders, many of whom hold significant influence on matters relating to any deployment of instructional technology. The purpose of this study was to examine the attitudes and perceptions of faculty governance

Ciabocchi, Elizabeth., Ginsberg, Amy \& Piacciano, Anthony (2016). A Study of Faculty Governance Leaders’ Perceptions of Online and Blended Learning. Online Learning 20 (3), 52 - 73. 
leaders to online education specifically as related to fully online courses, blended learning, and MOOCdeveloped courseware.

\section{Review of Literature}

This article will treat online education as it came to be on the Internet and World Wide Web starting in the early 1990s. Although online education applications using local and wide area networks existed before the Internet, the primary model that evolved over the past twenty years relies on ubiquitous data communications that are owned and operated routinely by most segments of the population. Today, large percentages of people living in countries throughout the world are using laptops, cell phones, and other portable devices to stay connected with family, friends, and their studies. The term online education is used to encompass all forms of teaching and learning using the Internet. It refers to the plethora of names and acronyms that have evolved over the past two decades, including online learning; e-learning; blended learning; distance learning; web-enhanced learning; hybrid learning; flipped classrooms; MOOCs (massive open online courses), and adaptive learning.

Internet-based online education, while a natural evolution of the instructional technology that has been a part of higher education since the middle of the $20^{\text {th }}$ century, is also a major leap forward in terms of how faculties teach and students learn. Online education is not simply an adjunct to the traditional classroom; it has replaced the classroom in many schools and programs. There are a number of very successful academic programs and colleges (i.e., University of Maryland - University College, Western Governors University, Rio Salado Community College) that now operate extensively on the Internet with few brick and mortar buildings. Approximately twenty-five to thirty percent of the college population or 5.5 to 7 million students are now enrolled in at least one fully online, for-credit course in any given year (Allen \& Seaman, 2016; Allen \& Seaman, 2015). An online course was defined in the Allen \& Seaman study as one where eighty percent of the seat time is replaced by online activity. Millions of other students are enrolled in blended or hybrid courses, although accurate data on this population is minimal, mainly because generally accepted definitions are non-existent. For the purposes of this article, the word "blended" will be used to designate courses in which a certain percentage of in-class time is replaced with online instruction and activities. The percentage of class time that occurs online varies by college and university, and typically ranges between $30 \%$ and $80 \%$. Web-enhanced courses that do not necessarily replace seat time, yet but have substantial Internet-based activity, are also becoming commonplace at all colleges and universities. MOOC providers offer close to 1,200 courses enrolling 1.3 million students (Sturgis, 2015). Most of these courses are not taken for credit. In sum, American higher education is reaching a point where the majority of college courses have some Internet components ranging from the fully online to Web-enhancements. In a mere twenty years, online education has become integral to instructional delivery in many colleges and universities.

As indicated earlier, faculty governance historically takes many forms within American higher education and includes faculty councils, collective bargaining organizations and unions, and as established in academic departments by institutional bylaws. The nature of faculty or shared governance is far from consistent in American higher education. In some colleges, faculty governing bodies maintain complete control over critical processes such as academic programs, curriculum, teaching standards, and assessments. In other colleges, especially at for-profit, private institutions, shared governance may be non-existent, and control of all processes rests with the administration. While faculty governance has a long history, it is not necessarily well understood. In a recent review, Bowen \& Tobin (2015) commented that there are three important aspects of faculty governance:

The first is that recent scholarship on American higher education pays scant attention to the role of faculty in governance; second, people in the academy know little about governance; and third,

Ciabocchi, Elizabeth., Ginsberg, Amy \& Piacciano, Anthony (2016). A Study of Faculty Governance Leaders’ Perceptions of Online and Blended Learning. Online Learning 20 (3), 52 - 73. 
governance must always be understood in the context of the times, as institutions confront different challenges and opportunities.” (p. ix)

To add to Bowen \& Tobin's comments, governance may also be local, i.e., it takes on different forms depending upon the nature of the institution, its culture, history, and location. Surely in many of the public and private non-profit colleges in the Northeast, where faculty governance has a long history and strong connections to organized labor, it is generally an influential force. In other parts of the country where organized labor is politically much weaker and where states have established right-to-work laws, faculty governance-particularly as exercised through collective bargaining organizations - tends to be limited. The growing number of large, private, for-profit colleges tends to have minimal faculty governance processes in place and employs large numbers of part-time faculty who have little influence on institutional decisions.

The literature on faculty governance in general is substantial; however, the number of studies that examine its relationship to online education and the attitudes of its leaders are few. This is not true for other members on the academy. Starting in 2003, Allen and Seaman (2015) have conducted yearly surveys of higher education chief academic officers examining their perceptions on a host of issues related to online education. The Campus Computing Project (2013) conducts regular surveys of presidents, provosts, and chief information officers regarding their views on instructional technology issues including online education. The Chronicle of Higher Education also conducts annual surveys of presidents on a host of issues and, in 2014, included their perceptions of developments in online education (Selingo, 2014). There have also been thousands of studies examining the attitudes of students and faculty on various aspects of online education. Entire refereed journals such as Online Learning (formerly the Journal of Asynchronous Learning Networks established in 1996), The Internet and Higher Education (established in 1998), and The Journal of Interactive Online Learning (established in 2001) are devoted entirely to publishing articles on online education, most of which examine issues such as student outcomes, student perceptions, and faculty perceptions. A review of the literature revealed that there are no empirical studies of the opinions or perceptions of faculty governance leaders regarding online learning. Rather, there are solely descriptive accounts and case studies examining faculty governance issues and online education in specific settings.

With its introduction in the 1990s, faculty governing bodies have been active in responding to the development of online education. Picciano (2006) described one such response at the City University of New York in June 1997, when the Professional Staff Congress (PSC), the collective bargaining organization representing faculty and other professionals, declared a moratorium on any form of distance learning. The PSC cited that the University had not established any policies related to this activity. Intellectual property, college governance procedures, workload, and additional compensation were among the issues that needed to be reconsidered (Kimmich, 1999). It was during this time that the National Education Association (NEA) and the American Federation of Teachers (AFT) issued position papers and recommendations to their affiliates urging faculty and administrators to reconsider collective bargaining agreements in light of the expansion of online distance learning activity (Kriger, 2001; Higher Education Program and Policy Council of the American Federation of Teachers, 2000). These issues also moved the NEA and AFT to commission the Institute for Higher Education Policy to conduct a study to examine issues of quality and practice to inform policymakers and collective bargaining negotiators on distance learning issues (Phipps \& Merisotis, 1999).

More recently, faculty governance drew a good deal of attention at San Jose State University where, in 2013, the president decided to enter into a contract with Udacity to develop six MOOC courses in basic mathematics and statistics. As the MOOC implementation unfolded at San Jose State, the University's Academic Senate became quite involved with a number of issues, but most notably how the

Ciabocchi, Elizabeth., Ginsberg, Amy \& Piacciano, Anthony (2016). A Study of Faculty Governance Leaders’ Perceptions of Online and Blended Learning. Online Learning 20 (3), 52 - 73. 
contract with Udacity was awarded. Its major concern was that faculty members were not consulted about the contract. In November 2013, after several months of discussion, academic leaders voted overwhelmingly in favor of a resolution asking the chancellor of the entire California State University system to review governance at San Jose State over the implementation of MOOCs. The resolution cited "a series of conflicts over the past year" that have highlighted "communication and transparency" issues and "opened serious rifts in our shared sense of community." The Academic Senate passed the resolution by a vote of 38 to 2, with five abstentions (Kolowich, 2013).

After several months of discussion, in an open letter to the campus, California State University Chancellor Timothy White (2014) cited Mohammad H. Qayoumi, President of San Jose State, as acknowledging that faculty, staff, and students had become frustrated and angered by the fast-paced actions "taken by me and members of my administration." Mr. Qayoumi said that, in trying to make progress on a series of goals for the university, he had "stepped on longstanding SJSU consultation practices and, as a result, harmed our practice of collegial shared governance." "For this," he continued, "I am regretful." Mr. Qayoumi pledged to "honor the consultative process" and said he was "committed to moving slowly where necessary,” allowing for consultation with a variety of groups (DeSantis, 2014).

In 2014, San Jose State University adopted a new policy regarding how "technology-intensive, hybrid, and online courses" may be created and run on its campus. The policy followed on the heels of concerns that university administrators—and particularly the president, Mohammad H. Qayoumi—had ignored the principles of shared governance. The new policy stated:

The university will not agree in a contract with any private or public entity to deliver technologyintensive, hybrid, or online courses or programs without the prior approval of the relevant department," using the "same department procedure" that is currently used to review changes in traditional courses. (Kolowich, 2014)

While San Jose State received a lot of attention regarding governance and the implementation of MOOCs and other forms of online education, similar discussions were being held in faculty governing bodies throughout the country.

Bowen \& Tobin (2015) conducted four case studies of faculty governance related to a host of issues including online education. Their original intent was to draw a sample of ten case studies but "it proved exceptionally difficult to construct a credible account of faculty governance roles based on available public sources" (Bowen and Tobin, 2015, p. 214). They concluded that any attempt to draw a representative sample of ten case studies was an illusion and an impossibility given the paucity of data in the historical record. Their four case studies were based on interviews and accounts at the University of California, Princeton University, Macalester College and the City University of New York. These institutions were selected mainly because the authors had access "through personal and professional relationships." The individual cases illustrated several issues related to faculty governance and are important examples of what occurred in these specific settings, but cannot in any way be generalized to the larger number of higher education institutions. While there were examples of the "we versus them" mentality in these case studies, there were also examples of where parties could come to mutual agreement.

The present study seeks to fill a void in the literature that focuses on the perceptions of faculty governance leaders to online education. As indicated in the Research Methods section to follow, identifying a sample of these leaders was difficult. This study is long overdue, but is timely given that American higher education is moving into a new wave of online education development spurred by significant financial investments by colleges, universities, and private enterprises. It is hoped that 
situations such as those that occurred at San Jose State University in 2013 can be avoided or ameliorated as more data are collected on the perceptions and attitudes of faculty governance leaders.

\section{Research Methods}

\section{Data Collection}

Survey research was the primary method for collecting data from faculty governance leaders. The survey included both Likert-scale and open-ended questions. The terms fully online, face-to-face, and blended or hybrid courses were used in the survey to distinguish the different instructional modalities. For the purposes of this survey, "blended" or "hybrid" refers to designate courses in which a certain percentage of in-class time is replaced with online instruction and activities.

In discussions with representatives of the American Association of University Professors, the major national organization for faculty governing bodies, a single email or other mailing list was not available. In addition, faculty leaders usually serve terms of one to two years and change on a fairly regular basis. Drawing a sample for this population proved difficult. Participants for this study were faculty governance leaders who were identified by searching through the individual chapter websites of the American Association of University Professors affiliated colleges (AAUP: http://www.aaup.org/about/aaup-chapter-websites). As a result of this search, 717 faculty governance leaders were identified at 144 colleges and universities throughout the United States and 2 American universities housed abroad. Requests for participation were emailed to these faculty governance leaders and 129 surveys were submitted, yielding a response rate of approximately 18\%. The first email request yielded the first 100 responses, with three reminders over the following four weeks bringing in the additional responses. The faculty governance leaders' survey was distributed via a proprietary system (SurveyMonkey).

Following the survey, the researchers emailed a set of open-ended follow-up items to 9 selfselected respondents who provided contact information for this purpose. All 9 respondents answered the following questions:

1) What is your position at your institution?

2) Please elaborate on what you think that American higher education needs to do to prepare better for the future (choices were: major transformation; to continue to evolve in a planned, careful manner; no major changes).

3) Please elaborate on the faculty governance bodies that review the development and approval of blended and online programs at your institution.

4) On average, results showed that respondents think that traditional (face-to-face) courses are of higher quality than blended courses and that blended courses are of higher quality than those that are fully online. Do you agree? If so, what do you think contributes to this? Is this the perception at your institution?

5) Is the overuse of adjunct faculty an issue at your institution, regardless of the modality (faceto-face, blended, or online)?

6) Are there any other comments or questions you have about this study?

Ciabocchi, Elizabeth., Ginsberg, Amy \& Piacciano, Anthony (2016). A Study of Faculty Governance Leaders’ Perceptions of Online and Blended Learning. Online Learning 20 (3), 52 - 73. 


\section{Data Analysis}

Quantitative and qualitative data analyses were conducted for the study. SurveyMonkey, a propriety survey tool, was used for survey distribution and for collecting basic descriptive statistics including cross-tabulation. Qualitative analysis of the responses to the written interview questions was also conducted by comparing and contrasting the interview responses to identify major themes in faculty perceptions of online learning. Categorical aggregation, a process of identifying meanings related to relevant issues in the study, was also employed (Miles \& Huberman, 1994).

\section{Findings}

\section{Initial Survey}

The majority of the survey respondents (73.64\%) represent public higher education institutions, followed by private, non-profit institutions (24.81\%) and private, for-profit institutions (1.55\%), respectively:

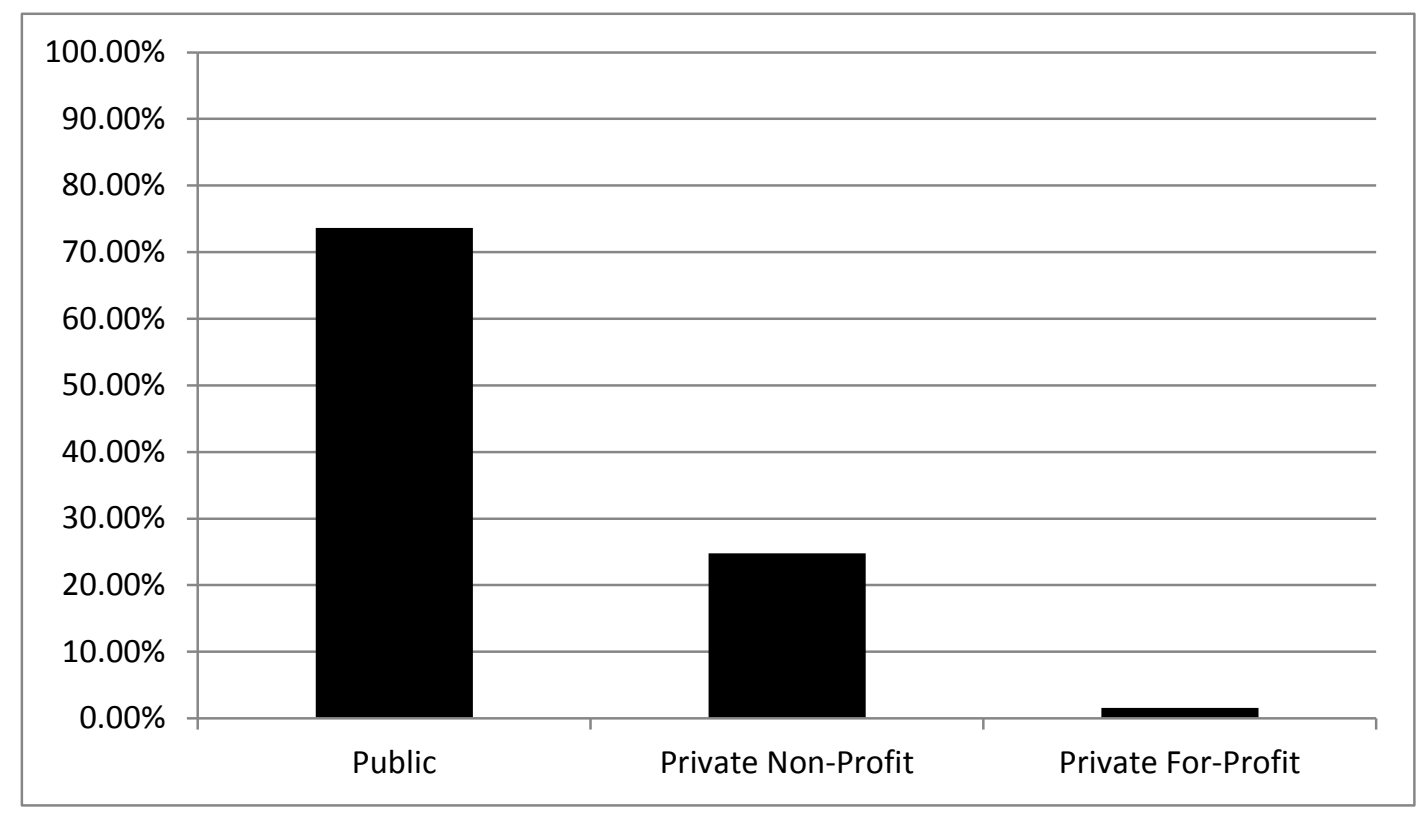

Figure 1: Higher Education Institutional Type

In terms of preparing for the future of higher education, the majority of respondents $(73.81 \%)$ believe that the sector needs to evolve in a planned, careful manner, versus undergoing a major transformation (23.02\%) or no major change at all (3.17\%): 
A Study of Faculty Governance Leaders’ Perceptions of Online and Blended Learning

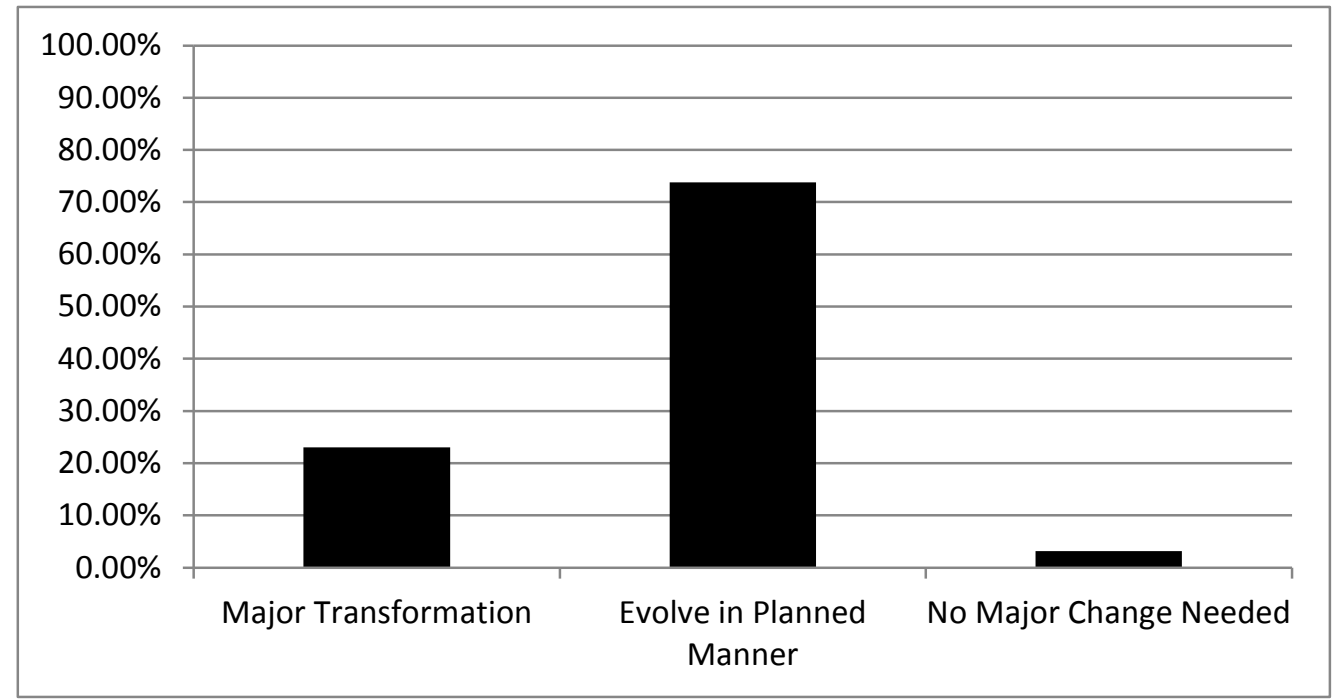

Figure 2: Preparation for the Future of Higher Education

The institutions represented by the survey respondents offer a range of program and course formats, including traditional degree and/or certificate programs (87.90\%); blended courses in traditional programs (78.23\%); blended degree/certificate programs (60.48\%); fully online courses in traditional programs (58.06\%): and fully online degree/certificate programs (45.16\%). Few of the respondents' institutions currently offer MOOCs (8.06\%):

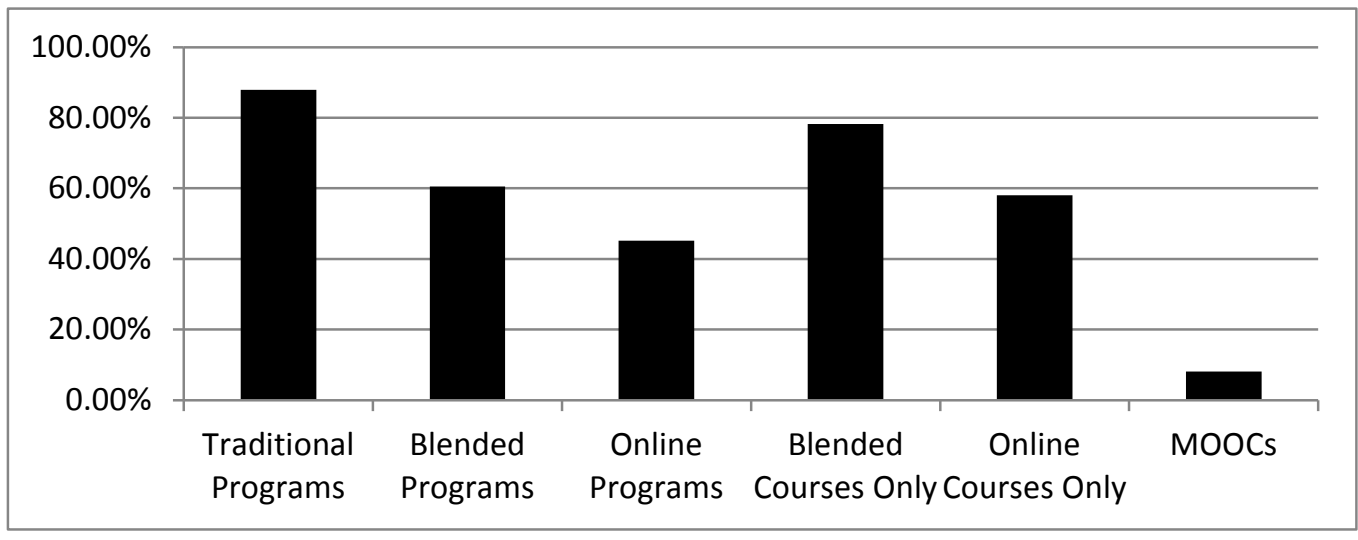

Figure 3: Course and Program Formats Offered by Institution

Additionally, the majority of respondents indicated that formal approval to offer blended and online programs is required at the departmental level (78.18\%), at the college or university level (70.91\%) and/or school level (56.36\%): 


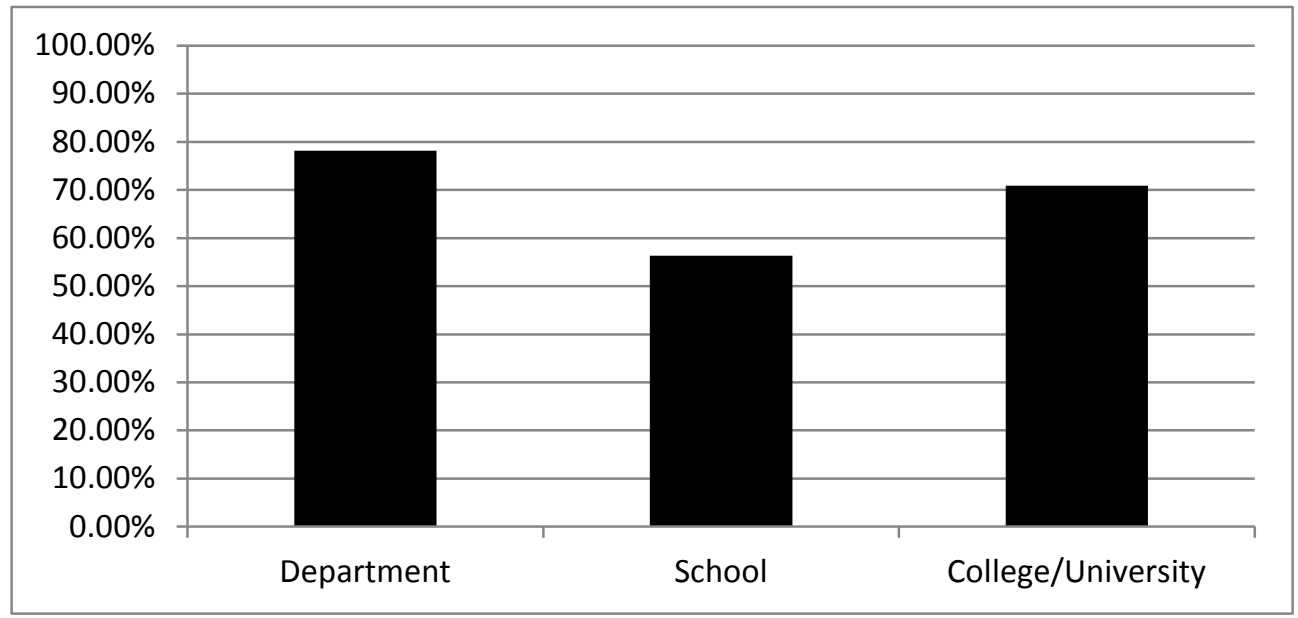

Figure 4: Levels of Formal Approval for Blended/Online Programs at Institution

Nearly all respondents (94.74\%) have developed or taught traditional courses. Many (50.88\%) have developed or taught blended courses, and fewer (38.60\%) have developed or taught fully online courses. None of the respondents has developed or taught a MOOC:

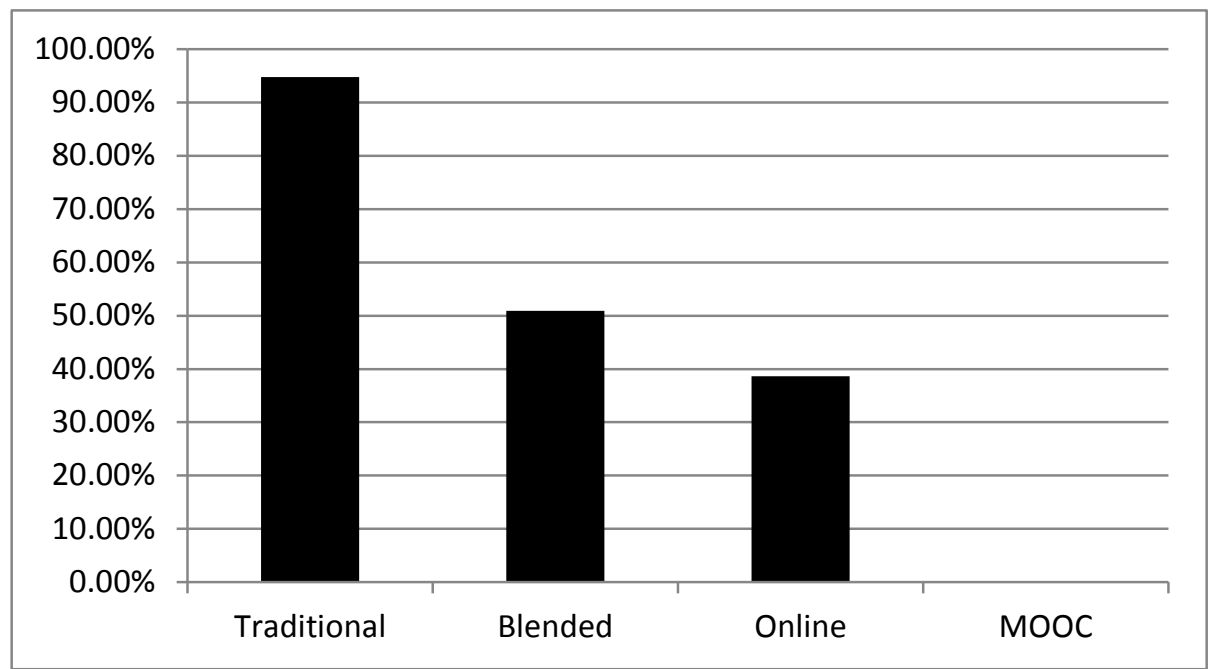

Figure 5: Course Formats Developed or Taught by Respondents

On a scale of 1 to 5 ( 5 being the highest score), respondents ranked the overall quality of courses offered at their institution highest for traditional courses/programs. Regarding the perceived quality of these different types of courses, on a scale of 1-5, with 5 being the highest, traditional courses received the highest average ranking (4.29), followed by blended courses/programs (3.26), fully online courses/programs (2.71) and MOOCs (1.79): 


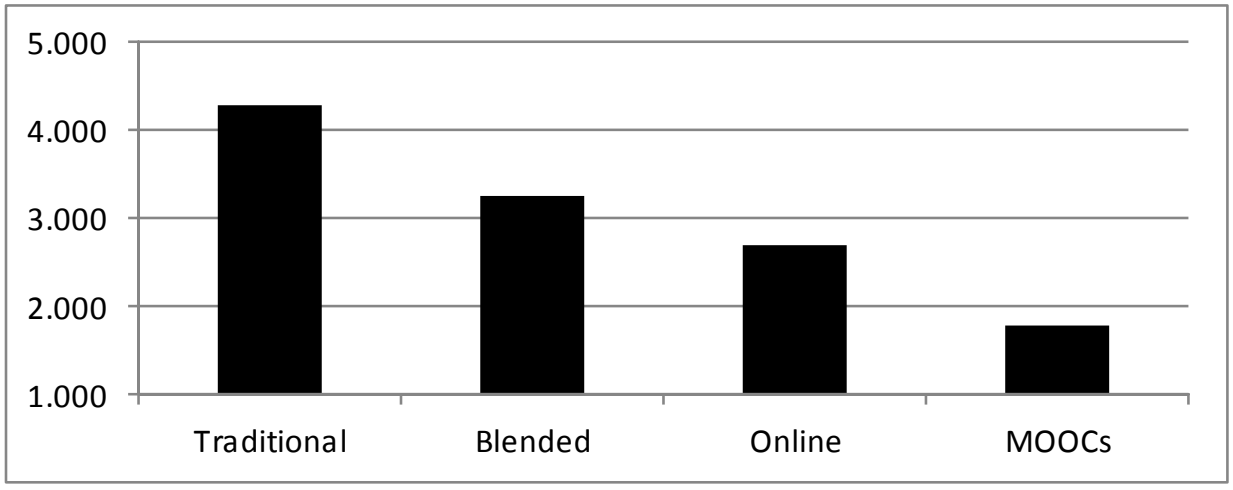

Figure 6: Overall Course Quality by Format

(Likert Scale of 1 - 5; 5 = Highest Score)

When asked to rate the quality of online, blended and traditional courses at their institution, all instructors ranked their institution's traditional courses considerably higher in quality than the institution's blended and online courses. However, experienced blended/online instructors also ranked the quality of their institutions' blended and online courses markedly higher (68\% and 55\% Satisfactory to Excellent, respectively) than did instructors who taught traditional courses only (55\% and 30\% Satisfactory to Excellent, respectively):

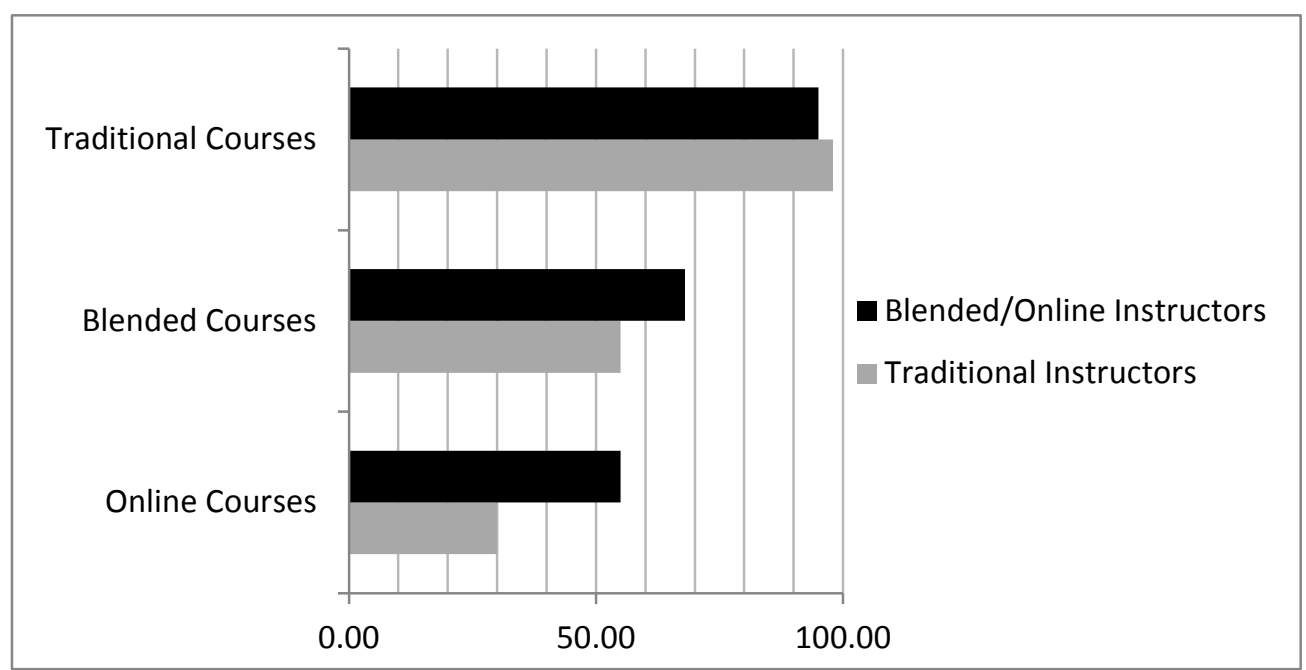

Figure 7: Perceptions of Course Quality by Format (\% of Satisfactory, Very Good and Excellent Rating)

In thinking about the development and implementation of blended and online courses at their institution, respondents were asked to rank their level of concern in a variety of areas: compensation for teaching; amount of time required to develop and deliver a course; perceived academic quality of course; student learning outcomes; time and effort for faculty development; faculty oversight of courses; intellectual property rights; instructional design support; technical support for faculty; technical support for students; student attrition, and overuse of adjunct faculty.

When asked to rank their level of concern regarding online course considerations on a scale of 1 (No Concern) to 5 (Very High Concern), respondents indicated their top 5 concerns as: 
1) Time required to develop and deliver a course (4.1)

2) Perceived academic quality of course and overuse of adjunct faculty (tie) (4.09)

3) Compensation for course design and development (3.97)

4) Student learning outcomes (3.94)

5) Time and effort for faculty development (3.92):

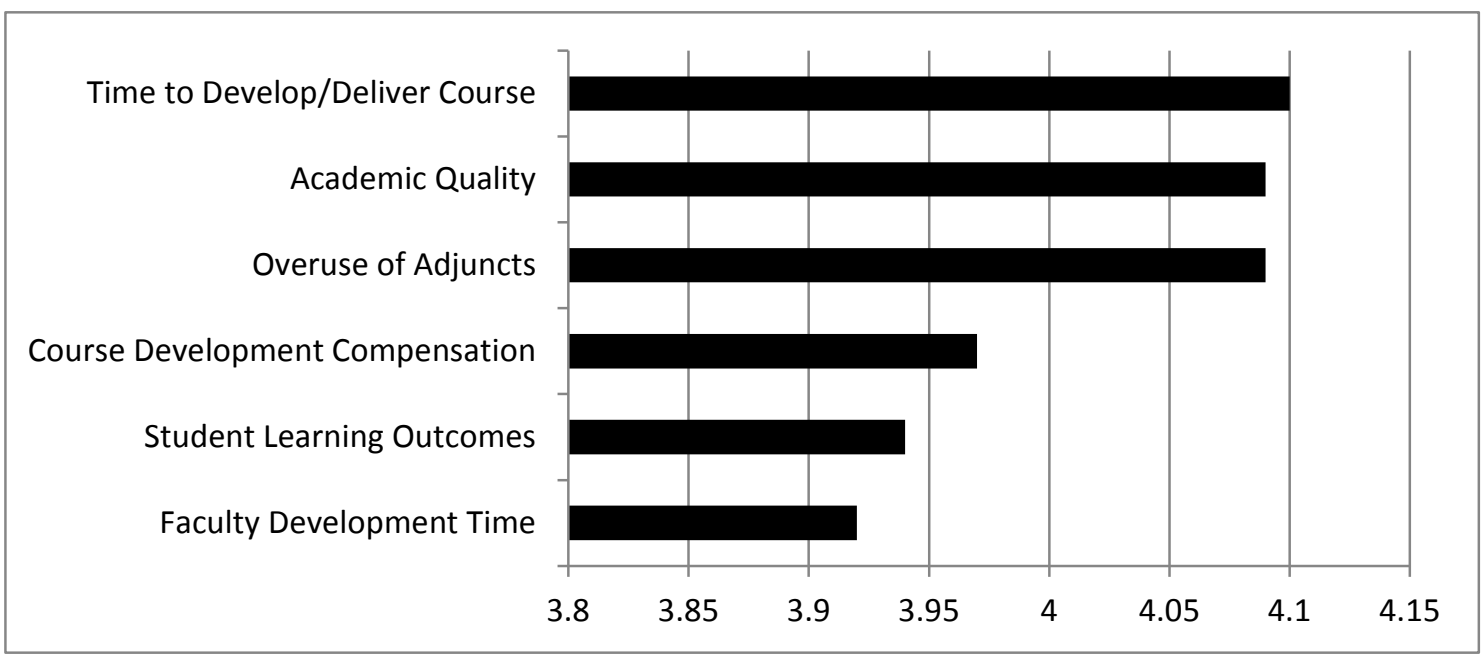

Figure 8: Top Concerns re: Online Course Considerations

Similarly, when asked to rank their level of concern regarding blended course considerations using the same scale, the top 5 concerns were:

1) Time required to develop and deliver a course (3.81)

2) Time and effort for faculty development (3.79)

3) Compensation for course design and development (3.78)

4) Overuse of adjunct faculty (3.77)

5) Student learning outcomes (3.54):

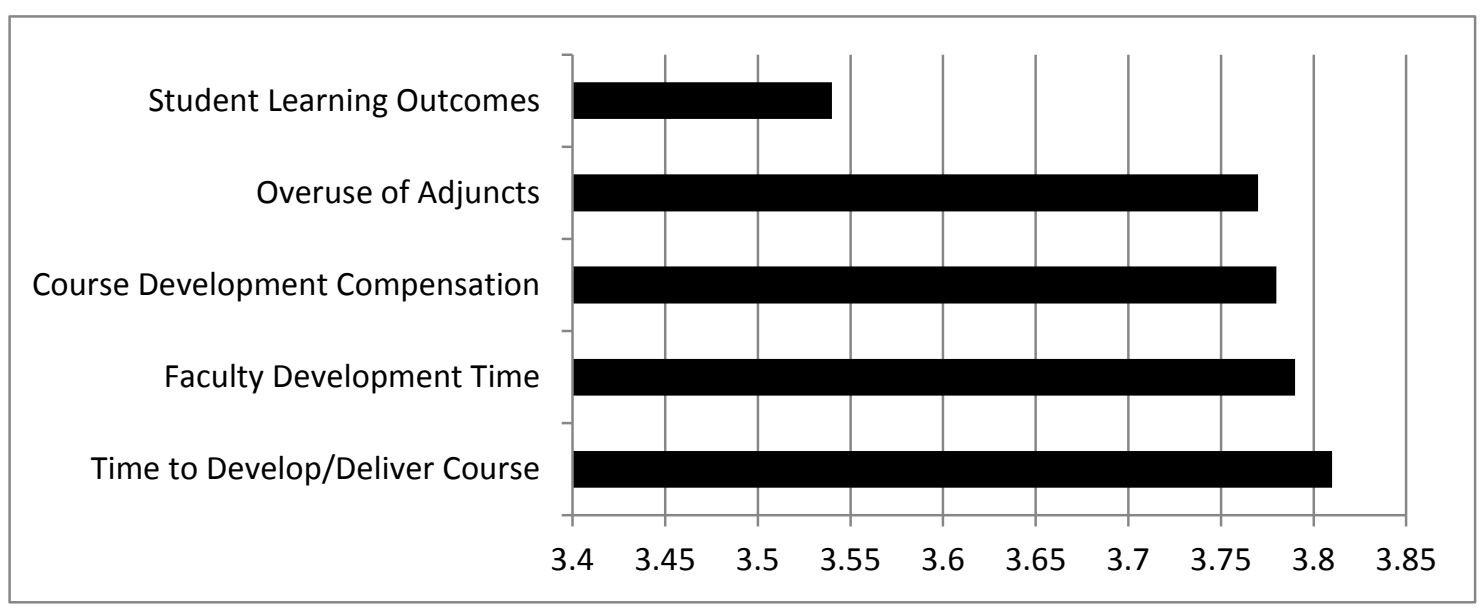

Figure 9: Top Concerns re: Blended Course Considerations

Ciabocchi, Elizabeth., Ginsberg, Amy \& Piacciano, Anthony (2016). A Study of Faculty Governance Leaders’ Perceptions of Online and Blended Learning. Online Learning 20 (3), 52 - 73. 
Traditional-only and blended/online instructors reported different levels of concern regarding the online and blended course considerations discussed previously. With respect to online courses, traditional-only instructors are more concerned about perceived academic quality; student attrition; faculty oversight; faculty development time; student learning outcomes and teaching compensation. Blended/online instructors, on the other hand, are more concerned about the overuse of adjunct faculty; technical support for students and faculty; instructional design support; intellectual property rights, time to develop/deliver courses, and course development compensation:

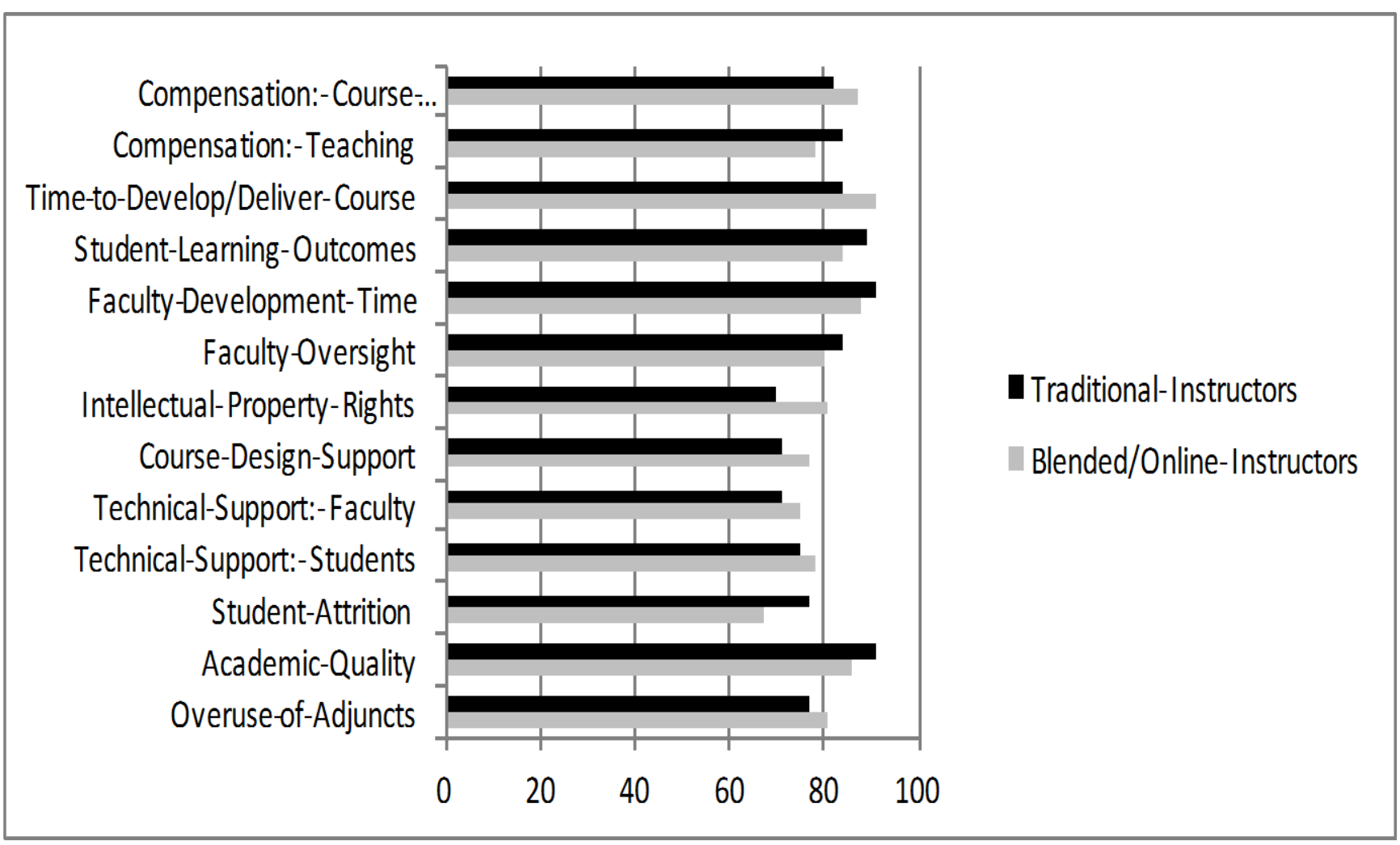

Figure 10: Level of Concern re: Online Course Considerations (\% of Moderate, High, and Very High Concern)

With respect to blended course considerations, traditional-only instructors were more concerned than blended/online instructors about compensation, student learning outcomes and student attrition in blended courses. Blended/online instructors were more concerned than traditional instructors about overuse of adjuncts; academic quality; technical support for students and faculty; instructional design support; intellectual property; faculty oversight; faculty development time, and the time to develop/deliver blended courses: 


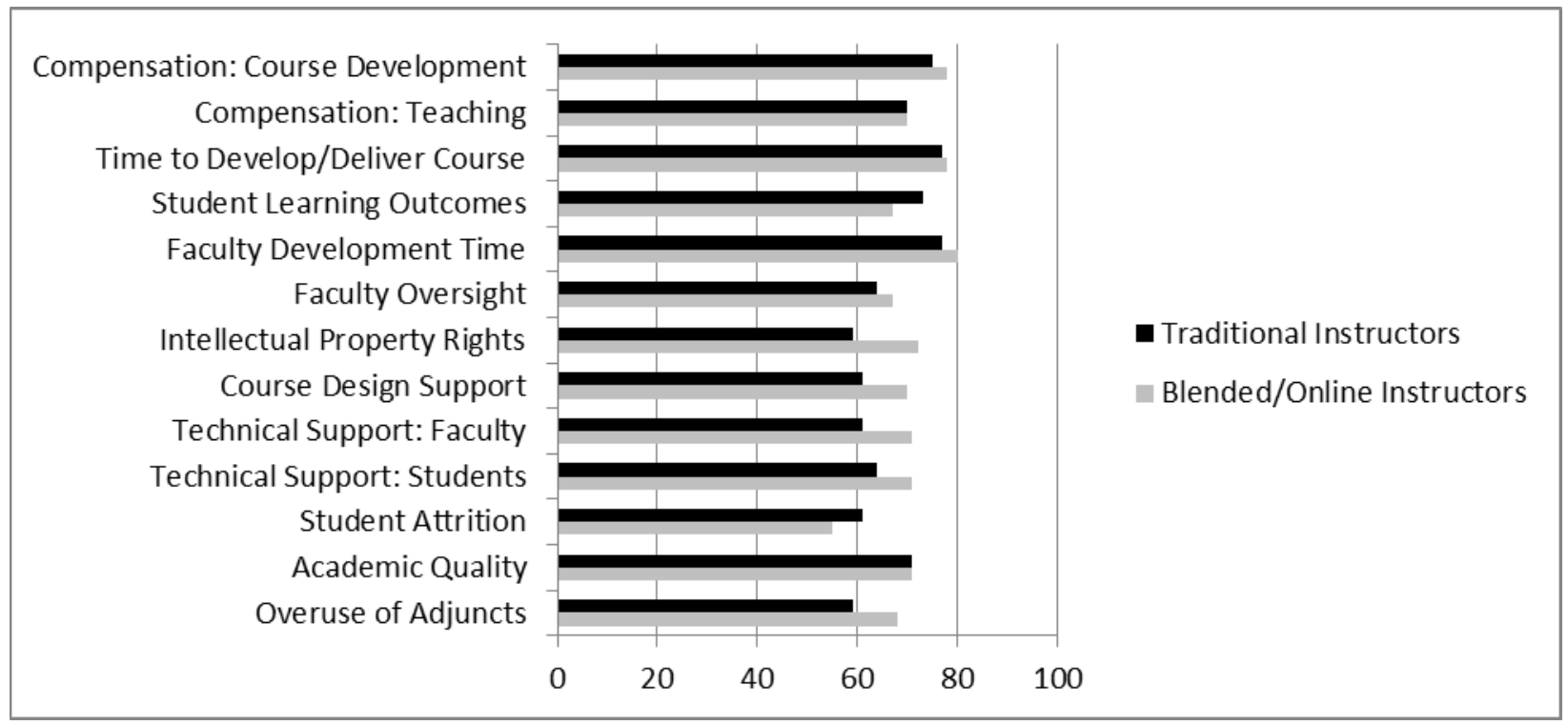

Figure 11: Level of Concern re: Blended Course Considerations (\% of Moderate, High and Very High Concern)

\section{Post-Survey Open-Ended Questions}

The nine survey respondents who volunteered to provide qualitative feedback in answering an additional set of questions ranged from instructors to full professors, and included non-tenured and tenured faculty from a diverse array of fields including management, foreign languages and nursing. Four themes emerged from the responses:

\section{Theme 1: American Higher Education Needs to Focus on Teaching to Better Prepare for the} Future.

Shared sentiments were that effective teaching needs to be valued and rewarded as much as faculty research. The perception was that because we now have a more diverse, and often not as wellprepared student body than previously existed, universities need to be able to meet these students' needs. Moreover, participants expressed skepticism regarding the ability and appropriateness of third-party course development companies to address the learning needs of particular student bodies. Quotes that exemplify this theme included:

$>$ "We need to focus on teaching and not publishing."

$>$ "It is important to keep tuition affordable."

$>$ "We need to encourage more students to get education in the technical and science fields."

$>$ "We have drastic cuts financially at many institutions and there are less faculty to teach increasing numbers of students with more diverse and challenging needs than ever before. We need to consider what those factors mean for institutions and teaching styles and integrate those ideas into our planning before faculty are directed to teach a certain way or to take on certain numbers of classes or class sizes or to teach online without any online experience."

$>$ "A big shift is going to have to take place where under-prepared students are taking an entire full year of college to learn the skills they should have picked up in high school."

$>$ "Professors are becoming mere content deliverers and degrees mere products to be bought. With this mindset seeping in it makes it easier for university administrators to rely on adjuncts and also in distance/online education this mindset allows for third-party 'course designers' etc. to encroach on the territory of the professor and corrupt the belief that there is learning for learning's sake... with the increase in distance/online education and other changes, faculty must 
fight to keep control and respect and to continue to be viewed as a professor not a content deliverer as much as possible."

$>$ "What American Higher Education needs to do for the future is diversify. We need to define what an education is, and what it isn't, and provide additional career pathways for students who don't need 'Introduction to Plato.' We don't need to cram younger students into the classroom; we need to fill our classrooms with students who know why they are there."

$>$ "Tenure must be preserved in order to keep universities from becoming more and more corporate in nature, with further grade inflation and less attention to the intellectual development of the students. Non-tenure-track teachers are by definition more likely to feel the pressure from students and from the administration to change the way they do things for all the wrong reasons."

$>$ "What's needed are new ways to communicate with students who live in a world where communication is evolving constantly. This doesn't preclude using traditional methods or 'new' ones, but those methods should be used with an understanding of how students interact with the world outside academia. The goal should be excellence, and the entire infrastructure of higher education should be focused on it with the intent of reaching as many students as possible in a way that is meaningful to them."

$>$ "I believe that the economic picture of higher education is our gravest concern... The mechanism of student aid has shifted away from grants and work-study when I was a student in the 1970s to loans, with financial institutions taking full advantage via predator practices... We need to level with students about the prospects of gaining employment to pay for their education... We need to streamline our education.”

\section{Theme 2: Faculty Review Processes Particular to the Development and Approval of Blended/Online Formats Are Needed}

There seems to be little structure in place particular to the development and approval of blended and online programs, although some reported that such processes and structures are in development. Quotes that exemplify this theme included:

“At our institution this is overseen mostly by curriculum committees at various levels throughout the university."

$>$ "I chaired a committee on online and hybrid courses that recommended such a committee. None has been created although one 'IT' committee has had its charge enlarged supposedly to oversee online issues, but neither the charge nor the way in which the committee operates is yet designed to review development of such courses."

$>$ "Blended and online courses are first developed by the individual faculty member with the assistance of their discipline and quite possibly division. Division chairs are involved in an advisory role. Once the faculty member is satisfied with the course, it goes to a Curriculum SubCouncil group, who reviews the course and makes suggestions for improvement, revision, changes, etc. That group then passes it to the Curriculum Council where the course is voted on. If it is passed, it is then incorporated into the program and can be added to the schedule of offered courses. Our entire process takes like a year for a course to get approved. And because our class schedules are available for students to view months in advance. For example, we have Spring 2016 schedules due like the end of August. So things happen very very slowly.”

$>$ Mainly we have a curriculum committee, which is composed of faculty members, usually someone from the registrar, and the provost for student services. I'm unclear on that though because they recently split into two different curriculum committees because of the workload and variety of complex issues, often related to online and blended/hybrid courses. Right now they are reworking the guide for developing courses (on ground, online, hybrid) and the rubrics used for evaluating them.”

Ciabocchi, Elizabeth., Ginsberg, Amy \& Piacciano, Anthony (2016). A Study of Faculty Governance Leaders’ Perceptions of Online and Blended Learning. Online Learning 20 (3), 52 - 73. 
> "We have a college-level Curriculum and Academic Affairs committee, which approves all courses, whether they are blended, on-line, or traditional. The C\&AA committee is made up of all the department chairs at the college, plus the head of the library."

$>$ "It is up to the departments - a course on the books can become blended (not sure about online) without a curricular change passing through the faculty-led committees."

$>$ "My college has a top-down management structure. Although faculty input is not disregarded, final decisions are always made by top administrators. New blended and online programs would go through the same process as traditional programs, which begins with development within the department, usually involving faculty and deans. The department dean would present the proposed program to the Vice President of Academic Services, who may or may not discuss it with the President before authorizing the dean to move forward. The program is then evaluated by the Course and Curriculum Committee, made up of faculty and administrators. Then it is sent on to the Academic Leadership Council (primarily faculty department chairs) for evaluation and approval. If approved, it is presented to the Board of Trustees for final authorization. Program review occurs roughly annually and is conducted by the chair of the department in consultation with other faculty and administrators. At this time, my college has no programs that can be completed only through online or blended classes."

$>$ "We had an ad hoc committee convene when the University had already approved an on-line College of Professional Studies for the adult, nontraditional population. Now there is a committee that supposedly addresses common concerns across our online and blended programs. As the director of an $80 \%$ on-line $\mathrm{PhD}$ Program I have to say that I am not on the committee and I have never heard from the committee about anything. There is a division between our professional school faculty and our arts and sciences faculty on the value and appropriateness of online education, with the professional schools being in favor and the arts and sciences faculty resisting mightily.”

\section{Theme 3: There is Skepticism Regarding Quality Assurance and Faculty/Student Preparation and Engagement in Online Learning}

Respondents shared that faculty are often not trained sufficiently to teach online, including how to engage with students to the same degree as in the face-to-face classroom, but that exceptions do exist. Moreover, respondents claimed that there is insufficient accountability in the online environment and a lack of clarity as to how to assess quality. Quotes that exemplify this theme included:

$>$ "Online courses are where marginal teachers meet marginal students for marginal results. Those who don't really want to teach meet those who do not really want to learn. Everyone is trying to just get by with the minimum of effort because they have something else they would rather do. I know this is harsh and not always true, but it usually is."

$>$ "There is not and never will be a substitute for hands-on learning along with face-to-face contact between student and teacher. While online courses certainly do have a place in higher education and can benefit many people, they do have their limitations, most of which are placed by the students on themselves. I teach both types of courses, and my experience has been that grades are better for students in traditional courses than in on-line courses, when the material taught is the same. There just seem to be either more students who take on-line courses for reasons other than to learn, or lack the motivation to do the work in an on-line course that does not have the structure of a face-to-face course."

$>$ "I think online courses can be very effective. I have been teaching online for a number of years but have also sought out workshops on this, gone to training sessions about this, read the literature on online teaching, and continue to work hard to improve my classes (as have a number of colleagues - all on our own time, by the way). This willingness to seek out the best ideas, share them, and continue to work to modify courses as needed and to consider which courses are best taught online and to what student population are all needed.”

Ciabocchi, Elizabeth., Ginsberg, Amy \& Piacciano, Anthony (2016). A Study of Faculty Governance Leaders’ Perceptions of Online and Blended Learning. Online Learning 20 (3), 52 - 73. 
> "The willingness of administrators to listen to faculty concerns and the willingness of a university to not let an IT group dictate how online learning occurs are also needed. This is not yet the perception at my university and, while there are some groups pushing for more faculty input, this is not uniform nor has significant progress been made across the university in this regard. There is a perception and a fact in some of the colleges that IT drives teaching rather than the other way around or a more balanced approach. If IT alone drives decisions, then there is a concern that... the desire to bring costs down (I've heard from a number of administrators that they see the 'value added' of online leaning to be lower costs) will impair quality rather than work to improve it."

$>$ "I think that it depends on the type of student. Some students just do much better in an online course than other students do. It really takes a lot of discipline on the part of the student. Some students can just never do well in an online course because they need the constant reminders and directions that a face to face class seems to provide. From what I hear at our institution, blended courses are the worst set-up... There is no specific rule about what blended even means. Is it 50/50 face time to online? 25/75, etc. Everyone does it differently-so most students are never satisfied with the breakdown... I guess my question would be - what does higher quality mean? We are supposed to have the exact same outcomes and objectives for a course regardless of whether it is face to face or online. So how is quality being measured? Grades of the students, evaluations of the instructor? They should be getting the same instruction just in a different format."

$>$ "Traditional courses are much higher quality, at least in my experience, because so much of my discipline (philosophy) relies on discussion. Although discussion boards can be interesting and stimulating in online classes, it's very much a different experience. Also, students have much more accountability when they actually attend a class. They feel more responsibility and much more involved and loyal to the course and the course materials. They are less likely to 'phone it in' so to speak or try to cheat, at least in my experience. In addition, so much of my students learning is from discussing things with other students in class or talking to me in my office hours and often this is not related directly to course lectures. Online students don't seem to feel as comfortable reaching out to me and getting to know me and thus they lose that important mentortype relationship that can really help students succeed in college and in life.”

$>$ "I actually think that blended courses are of the highest quality. This modality puts more responsibility on the student (they can't just show up for lecture) but preserves the advantages of meeting face-to-face."

$>$ "I definitely think that the give-and-take in a classroom with a professor leads to a more engaged student body. Done well (of course) classroom discussions, by virtue of the physical presence of individuals, are more compelling and the students feel far more invested in what they are doing than if it were online."

$>$ "My view is that there has been a lack of commitment to excellence in blended or online courses, which leads to both the perception and the reality of a lack of quality. Essentially, online and blended courses are seen as less challenging by students, largely because instructors have allowed this perception to become reality. If the instructors approach online and blended classes with the same expectation of excellence they have in traditional courses, there is no reason online and blended courses can't reach the same level of quality. At my institution, I would say the majority of my colleagues in faculty and administration see online and blended courses as inherently lacking in quality when compared to traditional. I think this perception comes from dependence on traditional methods that have been used throughout long careers, lack of experience or interest in online and blended teaching, and a cursory understanding of some literature.” 


\section{Theme 4: The Overuse of Adjunct Faculty is a Strong Concern in Blended/Online Higher Education}

Quotes that exemplify this theme included:

$>$ "There is pressure to use them [adjunct faculty] for distance learning to just bump up the numbers."

$>$ "At least full-time faculty typically know courses well, so if they are asked to teach more or teach online, they are at least very familiar with the content. The same can’t be said for adjuncts, so if there is not good gatekeeping and planning (small enough classes, proof of ability to teach online, etc.), then the experience for teachers and students is not going to be as good for anyone, but especially with adjuncts who may be less familiar with the particular courses and students."

$>$ "Adjunct faculty are becoming more and more of a problem especially in the nursing programs that are largely online. They have adjuncts and teach multiple sections and then they have "super adjuncts" that can organize the other adjuncts. This is a huge threat to full time faculty and it is incredibly sad how little money, job security and benefits the adjuncts receive. Not to the mention the fact that their status as an adjunct is largely hidden from students and even full time faculty do not know how many adjuncts there are.”

\section{Discussion}

Despite the fact that the demand for blended and online courses continues to increase in higher education institutions, along with faculty participation in blended and online teaching and learning, the current study demonstrates that faculty governance leaders remain generally skeptical about the academic quality and rigor of blended and online courses as compared to courses offered in a traditional format at their respective institutions. The faculty governance leaders who participated in this study were well familiar with teaching in fully online (nearly 40\%) and blended (50\%) learning environments, which indicates direct experience with the issues and concerns they reported in this study, namely, the time required to develop and deliver courses; academic quality of courses; compensation for teaching such courses; time and effort required for faculty development in blended/online teaching and learning, and a perceived overuse of adjunct faculty to teach blended/online courses.

Not surprisingly, faculty governance leaders with prior blended/online teaching experience rated the academic quality of their institution's blended/online offerings higher than did colleagues with no online teaching experience. Yet, they continue to perceive blended/online courses to be lower in quality as compared to their institution's traditional offerings. The findings are consistent with other studies regarding faculty attitudes toward blended/online teaching and learning. In a sample of over 4,000 higher education faculty members (full-time and part-time, tenured and not) from a wide range of institutions (public and private, non-profit and for profit, two-year and four-year), Allen and Seaman (2012) found that nearly two-thirds of faculty reported the perception that face-to-face courses produce superior learning outcomes in comparison to online courses. This finding was most prevalent for those with the least exposure to online education. Faculty members with direct online teaching experience were the most positive about the quality of student learning in online courses. Perhaps in acknowledgement of the inevitability of online education, 60 percent of faculty referred students to an online course, despite concerns about learning outcomes. However, this varied widely depending on the faculty member's previous online teaching experience; 49 percent of those who had not taught online recommended an online course in comparison to 87 percent of those who had taught online. Still, it is notable that just about half of this large sample of faculty who had not taught online and were skeptical about learning outcomes still recommended online courses to students.

The data collected for this study show that some participants believe that online courses suffer from poor quality due to lack of appropriate professional development for the faculty in online pedagogy 
that facilitates student engagement; students who are more interested in earning a credential than in academic rigor in online courses; faculty (especially adjuncts) who lack motivation and/or incentives to uphold high academic standards in online courses, and lack of accountability and quality control in online courses. However, it is possible that resistance to online learning stems from psychological factors as well as external experience. Bunk, Li, Smidt, Bidetti and Malize (2015) found that excitement versus fear mediates the relationship between online teaching experience and faculty attitudes about online education. With items from the survey instrument used by Allen and Seaman (2012) referenced above, Bunk and his colleagues found that faculty perceptions that their institution was pushing too much instruction online were greatest among those who had more fear than excitement and had no experience teaching online. However, feelings of excitement and/or fear did not predict faculty perceptions of online teaching effectiveness or learning outcomes. Further investigation into other psychological and character traits such as persistence, locus of control, and self-efficacy may prove fruitful toward better understanding of perceptions on online teaching effectiveness and learning outcomes.

There is also concern related to the perception that online courses require more work and take up more faculty time than do face-to-face courses. Research supports this view (Cavanaugh, 2005; Ryan, Tynan, and Lamont-Mills, 2014; Tomei, 2004). Tomei (2004) reported on the amount of contact time required for an instructor teaching the same class to two groups of students, one class in the traditional face-to-face format and the other online. Each class included 11 students who self-selected the modality in which they would learn, and the instructor was experienced in teaching the course in both modalities. Tomei measured the number of classroom/instructional content hours, student counsel and advisement hours, and student assessment hours, and concluded that he spent $14 \%$ more hours for the online course in comparison to the traditional course. Moreover, Tomei's figures suggested that ideal class sizes are smaller for online courses $(n=12)$ compared to face-to-face courses $(n=17)$. Other researchers (e.g., Cavanaugh, 2005) have argued that teaching online is one-and-a-half or two times as much work as teaching face-to-face. Instructional designers and experienced online instructors warn those new to online teaching to guard against the "course-and-a-half" phenomenon, in which both faculty and students are overburdened.

Going forward, it is important to continue to identify and address the root causes of the faculty's perception that blended/online offerings are of inferior academic quality, despite a growing body of evidence such as the following, which indicate that blended and online courses can result in student learning outcomes equivalent to those achieved in face-to-face courses. Stack (2015) reported on the teaching of two sections of a course, one online and one face-to-face. Students were not able to self-select due to an administrative error in the course schedule, which eliminated the potential confounding factor of selection bias. The instructor gave a standardized final examination and proctored it himself for both sections, eliminating another limitation in some studies on the assessment of learning in online courses (lack of proctoring of exams in online sections). Results showed no significant difference between exam scores (and, parenthetically, no difference in student evaluations of the course). A large sample comparison of student learning outcomes in online versus face-to-face courses similarly revealed no overall difference in grade-based student performance between instructional modes (Cavanaugh \& Jacquemin, 2015). Scratching under the surface of this overall finding revealed that students with higher GPAs performed even better in online courses compared to face-to-face courses, whereas students with low GPAs performed worse in the online format compared to face-to-face. Further exploration stemming from this recent finding is warranted.

Some have argued that technology can play an important role in improving student learning outcomes for traditional and online education (Cain \& Pitre, 2008; Prineas \& Cini, 2011). After controlling for demographic variables of 2,000 students in traditional college classrooms, Cain and Pitre (2008) found that the inclusion of technology tools and resources explained $4 \%$ to $7 \%$ of student learning

Ciabocchi, Elizabeth., Ginsberg, Amy \& Piacciano, Anthony (2016). A Study of Faculty Governance Leaders’ Perceptions of Online and Blended Learning. Online Learning 20 (3), 52 - 73. 
gains, a modest yet significant finding. In the online environment, learning analytics permit the design of data-driven interventions to support student learning and initiatives focused on mastery learning (e.g., Kahn Academy) may close the gap between assessment and learning though continual feedback loops for students, instructors, and course designers (Prineas \& Cini, 2011).

The more familiar faculty governance leaders are with the research around student learning in online and blended environments the better. Moreover, faculty governance leaders should be encouraged to support research efforts at their own universities with their particular faculty, students, and courses. A model might be found in the University of Massachusetts Amherst Faculty Senate Ad Hoc Committee on Online Learning, whose Comparative Outcomes Subcommittee engaged in a comparison of undergraduate student outcomes in online and face-to-face courses (Stassen, Blaustein, Rogers \& Shih, 2007). The same instructor, exams, and course materials used in online and face-to-face courses were compared. Bivariate comparisons revealed no statistically significant differences on student performance as measured by total exam score, score on online homework, grades on two project-based assignments, and final course grade. Multivariate regression analyses were largely consistent, supporting the conclusion that minimal differences existed in student learning outcomes across the two instructional formats. We applaud the efforts of this faculty governance body and call for more faculty governance support of this kind.

\section{Conclusion}

In closing, this paper was based on a study of the attitudes and perceptions of higher education faculty governance leaders regarding online education, specifically as related to fully online and blended courses and programs, and MOOC-developed courseware. The study provided helpful insights using basic survey methodology and a limited number of qualitative interviews. In many colleges and universities with traditional faculty governance structures, this group can have a major influence on pedagogical practices including online learning modalities; therefore, additional qualitative research is recommended to delve more deeply into academic decision-making and provide greater context for these complex administrative processes. For example, given some of the disparities in participants' perceptions of online and blended learning, future research might include additional institutional factors that may influence faculty governance leaders' dispositions toward online/blended formats including the level of professional development in online/blended learning for full-time and adjunct faculty; technical support and services for faculty and students; scale and maturation of online/blended courses and programs; average class size of online/blended courses; concerns regarding academic integrity of online/blended courses, and institutional commitment to online/blended learning as evidenced by strategic planning and resource allocation. As additional data become available, universities will be increasingly able to make academically prudent decisions about blended and online learning at their institutions and allocate resources and support as necessary to facilitate student learning success across instructional modalities.

Ciabocchi, Elizabeth., Ginsberg, Amy \& Piacciano, Anthony (2016). A Study of Faculty Governance Leaders’ Perceptions of Online and Blended Learning. Online Learning 20 (3), 52 - 73. 


\section{References}

Allen, E \& Seaman, J. (2016). Online report card: Tracking online education in the United States. Needham, MA: Babson College Survey Research Group.

Allen, E \& Seaman, J. (2015). Grade level: Tracking online education in the United States. Needham, MA: Babson College Survey Research Group.

Bowen, W. G. \& Tobin, E.M. (2015). Locus of authority: The evolution of faculty roles in the governance of higher education. Princeton: Princeton University Press.

Cain, D. L., \& Pitre, P. E. (2008). The effect of computer mediated conferencing and computer assisted instruction on student learning outcomes. Journal of Asynchronous Learning Networks, 12(3), $31-52$.

Cavanaugh, J. (2005). Teaching online - A time comparison. Online Journal of Distance Learning Administration, 8(1). Retrieved from: https://www.westga.edu/ distance/ojdla/spring81/cavanaugh81.htm

Cavanaugh, J. K., \& Jacquemin, S. J. (2015). A large sample comparison of grade based student learning outcomes in online vs. face-to-face courses. Online Learning Journal, 19(2). Retrieved from: http://olj.onlinelearningconsortium.org/index.php/olj/article/view/454/138

DeSantis, N. (May 13, 2014). San Jose State U. Chief vows reforms after clashes over governance. The Chronicle of Higher Education. Retrieved from: http://chronicle.com/blogs/ticker/san-jose-stateu-s-president-vows-reforms-after-clashes-over-campus-governance/77543

de Vise, D. \& Kumar, A. (June 13, 2012). Teresa Sullivan ouster: 33 faculty leaders protest her dismissal from University of Virginia presidency. The Washington Post. Retrieved from: http://www.washingtonpost.com/blogs/virginia-politics/post/university-of-virginia-departmentchairs-protest-teresa-sullivan-ouster/2012/06/13/gJQA90tTaV_blog.html

Devons, S. (Summer 2001). I.I. Rabi: Physics and science at Columbia, in America, and worldwide. Living Legacies: Great Moments and Leading Figures in the History of Columbia University. Retrieved from: http://www.columbia.edu/cu/alumni/Magazine/Summer2001/Rabi.html

Higher Education Program and Policy Council of the American Federation of Teachers (May, 2000). Distance education: Guidelines for good practice. Washington, D.C.: American Federation of Teachers. Retrieved from: http://www.aft.org/pubs reports/higher_ed/distance.pdf

Kimmich, C. (1999). Letter from Interim Chancellor Christoph Kimmich to College Presidents dated March 22nd. Subject: Distance Learning.

Kolowich, S. (January 31, 2014). San Jose State U. adopts new policy for online and 'hybrid' courses. The Chronicle of Higher Education. Retrieved from: http://chronicle.com/blogs/wiredcampus/san-jose-state-u-adopts-new-policy-for-online-andhybrid-courses/50029

Ciabocchi, Elizabeth., Ginsberg, Amy \& Piacciano, Anthony (2016). A Study of Faculty Governance Leaders’ Perceptions of Online and Blended Learning. Online Learning 20 (3), 52 - 73. 
Kolowich, S. (November 19, 2013). Citing a series of conflicts, San Jose State U. asks for governance review. The Chronicle of Higher Education. Retrieved from: http://chronicle.com/article/AsMOOC-Debate-Simmers-at-San/139147/.

Kriger, T. (May, 2001). A virtual revolution: Trends in the expansion of distance education. Washington, D.C.: American Federation of Teachers. Retrieved from: http://www.aft.org/pubsreports/higher_ed/VirtualRevolution.pdf

Miles, M.B. \& Huberman, A. M. (1994). Qualitative Data Analysis. Thousand Oaks, CA: SAGE Publications, Inc.

Perez-Pena, T. (June 26, 2012). Ousted head of university is reinstated in Virginia. New York Times. Retrieved from: http://www.nytimes.com/2012/06/27/education/university-of-virginia-reinstatesousted-president.html

Phipps, R. \& Merisotis, J. (1999). What's the difference: A review of contemporary research on the effectiveness of distance learning in higher education. Washington, D.C.: The Institute for Higher Education Policy.

Picciano, A.G. (2006). Online learning: Implications for higher education pedagogy and policy. Journal of Thought, 41 (1), pp. 75-94.

Prineas, M. \& Cini, M. (2011). Assessing learning in online education: the role of technology in improving learning outcomes (Occasional Paper \#12). National Institute for Learning Outcomes Assessment. Retrieved May 10, 2016 from http://www.learningoutcomeassessment.org/documents/onlineed.pdf

Ryan, Y., Tynan, B., \& Lamont-Mills, A. (2014). Out of hours: Online and blended learning workload in Australian Universities. In A. G. Picciano, C. D. Dziuban, \& C. R. Graham (Eds.), Blended learning: Research perspectives, Vol. 2 (pp. 268-283).

Selingo, J.J. (Editor) (2014). The innovative university: What college presidents think about change in American higher education. The Chronicle of Higher Education and McGuire Associates. Retrieved from: http://app.results.chronicle.com/e/es.aspx?s=2423\&e=89593\&elq=cd9973526e504845837bbada1 $\underline{6 \mathrm{e} 5 \mathrm{~b} 345}$

Stack, S. (2015). Learning outcomes in an online vs traditional course. International Journal for the Scholarship of Teaching and Learning, 9(1), Article 5. Retrieved from: http://digitalcommons.georgiasouthern.edu/ij-sotl/vol9/iss1/5

Stassen, M., Blaustein, M., Rogers, R., \& Shih, M.-Y. (2007). Undergraduate student outcomes: A comparison of online and face-to-face courses. Office of Academic Planning and Assessment, University of Massachusetts Amherst. Retrieved from http://www.umass.edu/oapa/oapa/publications/misc_docs/undergrad-student-outcomes.pdf

Sturgis, I. (2015). MOOCs: More hype than hope. Convergence: Diversity and Inclusion. Supplement to The Chronicle of Higher Education.

Ciabocchi, Elizabeth., Ginsberg, Amy \& Piacciano, Anthony (2016). A Study of Faculty Governance Leaders’ Perceptions of Online and Blended Learning. Online Learning 20 (3), 52 - 73. 
The Campus Computing Project (2013). Welcome to the Campus Computing Project. Retrieved August 1, 2015 from: http://www.campuscomputing.net/.

Tomei, L. (2004). The impact of online teaching on faculty load. International Journal of Instructional Technology and Distance Learning, 1(1), 3-45.

White, T. (May 8, 2014). Open letter to the students, faculty, staff, and friends of San Jose State University. California State University - Office of the Chancellor. Retrieved from: http://www.docstoc.com/docs/169779759/sjsu_administrative_review.pdf 